\section{Oslo universitetssykehus HF}

Oslo universitetssykehus HF (OUS) er landets største sykehus og eies av Helse Sør-Øst RHF. Helseforetaket består av Aker sykehus, Ullevål sykehus, Rikshospitalet, Radiumhospitalet, Geilomo, Spesialsykehuset for epilepsi - SSE og en rekke mindre virksomheter i Østlandsområdet. Oslo universitetssykehus leverer spesialisthelsetjenester og ivaretar både lands-, regions-, område- og lokalfunksjoner.

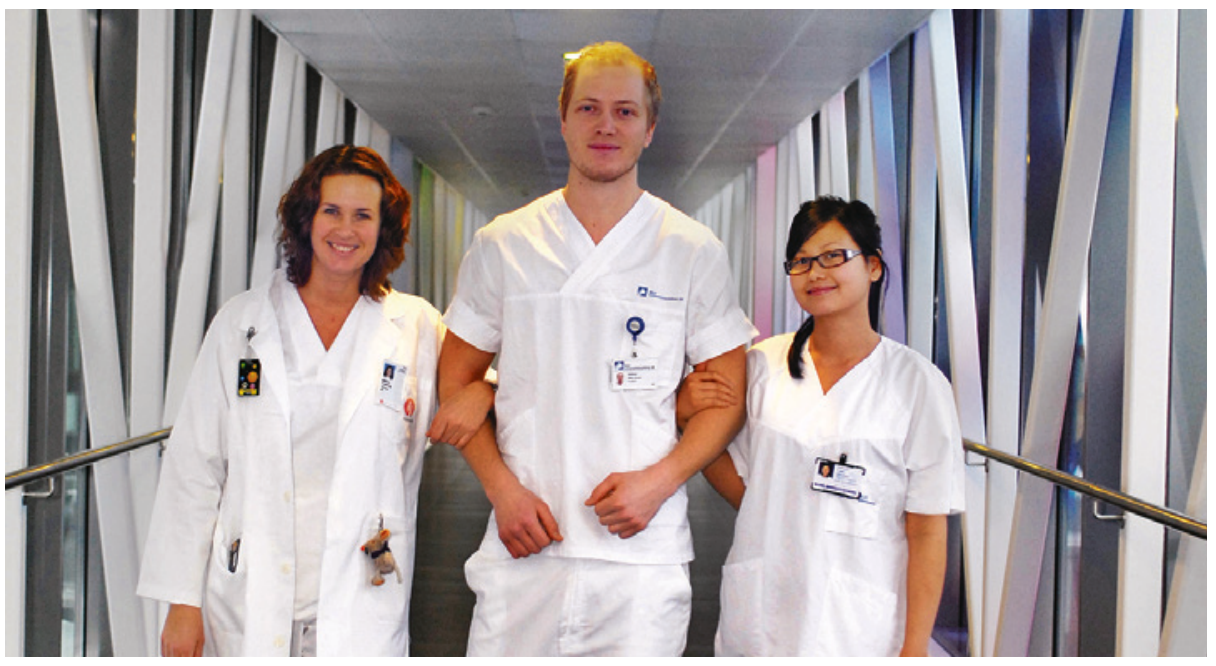

Foto: Oslo universitetssykehus

Ved Oslo universitetssykehus tar vi utgangspunkt i pasientens perspektiv. Vi skal ha et arbeidsmiljø preget av åpenhet og respekt, være et fremragende universitetssykehus med en lærende og skapende organisasjon, en god samarbeidspartner og en engasjert samfunnsaktør.

Oslo universitetssykehus' verdier bygger på kvalitet, trygghet og respekt. Vår kultur skal være åpen, lærende og helhetsskapende. Sykehusets hovedoppgaver er pasientbehandling, forskning, utdanning av helsepersonell og opplæring av pasienter og pårørende.

\section{Kort historikk}

Helse Sør og Helse Øst ble slått sammen til Helse Sør-Øst 1. juli 2007. Et av hovedmålene var å få etablert en bedre sykehusstruktur i Oslo. Høsten 2008 vedtok styret i Helse Sør-Øst å dele inn regionen i sykehusområder med helseforetak som skal gi et helhetlig tilbud til befolkningen. Oslo universitetssykehus ble etablert 1. januar 2009 da helseforetakene Ullevål, Aker og Rikshospitalet/Radiumhospitalet ble slått sammen. Fra 1. januar 2011 fikk foretakets nye organisasjonsmodell effekt for pasientbehandlingen gjennom en klinikkstruktur som gikk på tvers av de fire fusjonerte sykehusene

\section{Et døgn på Oslo universitetssykehus}

3300 pasienter behandles, det er 360 ambulanseoppdrag, 1800 pasienttransporter, 2000 portøroppdrag, 26 barn fødes, 48,4 millioner kroner i budsjett, 15000 mennesker på jobb, 2160 middager serveres, 15 tonn sengetøy og uniformer vaskes.

\section{Forskningen ved Oslo universitetssykehus}

Oslo universitetssykehus står for halvparten av all forskning som gjøres ved norske sykehus. Det skjer i samarbeid med Universitetet i Oslo, høyskoler og en rekke nasjonale og internasjonale miljøer. Det ble gjennomført 118 doktorgrader og publisert 1590 vitenskapelige artikler i 2010. Vi har tre sentre for fremragende forskning, svært gode resultater i Forskningsrådets evaluering av forskningsmiljøer i 2011, og fungerer som forskningsstøtte for sykehusene i Helse Sør-Øst. Forskning er sentralt også innen landsfunksjoner og nasjonale kompetansetjenester.
13.10.

FRIST FOR REGISTRERING AV ANNONSER TIL NR. 20/2014 PÅ LEGEJOBBER.NO

\section{Om Legejobber.no}

Legejobber.no er Tidsskriftets stillingsportal for leger og for stillingsannonsører.

Som annonsør kan du nå bestille annonsen døgnet rundt via Legejobber.no. Du registrerer nettannonsen og papirannonsen samtidig.

\section{Som jobbsøker kan du på Legejobber.no enkelt søke etter ledige jobber etter spesialitet, geografisk område eller i fritekst.}

\section{Ønsker du å motta varsel \\ om ledige stillinger innenfor \\ et bestemt område? \\ På Legejobber.no kan du \\ abonnere på ledige stillinger.}

\section{Priser på stillingsannonser 2014}

* Gjelder for kombinasjon papir/nett.

Format

Størrelse

1/1 side

$185 \times 245$

Pris svart-hvitt

31600

Pris 4 farger

34700

$1 / 2$ s. liggende

$185 \times 112$

Pris svart-hvitt

17000

Pris 4 farger

20000

1/2 s. stående

$90 \times 245$

Pris svart-hvitt

17000

Pris 4 farger

20000

$1 / 4$ side

$90 \times 112$

Pris svart-hvitt

9000

Pris 4 farger

11000

$1 / 8$ side

$90 \times 45$

Pris svart-hvitt

6100

Pris 4 farger 